\title{
Что нам нужно для эффективной коммуникации?
}

(Рецензия на книгу: Эффективность коммуникации: понятие, роль адресата и адресанта, основные приемы ее достижения: монография / под ред. О.Б. Сиротиной, М.А. Кормилицыной. Саратов: Наука, 2019)

Татьяна Сурикова

(C) Сурикова Татьяна Ивановна доцент кафедры стилистики русского языка факультета журналистики МГУ имени М.В. Ломоносова (г. Москва, Россия), surikova_t@mail.ru
Названная коллективная монография продолжает исследование условий успешной коммуникации, которое было начато более 20 лет назад книгой с красноречивым названием "Хорошая речь» (Кормилицына, Сиротина (ред.), 2001). Несколько лет назад вышла «Рискогенность современной коммуникации и роль коммуникативной компетентности в ее преодолении» (Сиротина, Кормилицына (ред.), 2015), так что обращение к обобщающей предыдущие наблюдения теме эффективности речевого общения закономерно. Такой ракурс требует научной смелости, поскольку, во-первых, начиная с античной риторики любое научное направление, исследующее язык, коммуникацию и речевое поведение, по крайней мере, имплицитно подразумевает достижение коммуникативной цели. Во-вторых, общепринятое понимание эффективности как степени соответствия результатов целям коммуникативного акта / кампании предполагает количественные измерения изменений в картине мира или в поведении реципиентов.

Количественный аспект эффективности коммуникации исследование не затрагивает. Но это не умаляет его досто- 
инств, поскольку количественным измерениям предшествует предварительное определение их критериев - создание сети измерительных координат. Более того, монография косвенно доказывает, что вряд ли подобные полноценные измерения вообще возможны, если иметь в виду не узконаправленные замеры изменений в потребительском / избирательском поведении целевой аудитории, а многоаспектную оценку воздействия любого сообщения на любого реципиента.

Как главная, поставлена амбициозная цель создания именно такой системы качественной оценки эффективности коммуникации, включая учет особенностей языкового сознания адресата и адресанта: иерархии ценностей, своеобразия когнитивных операций при вербализации действительности. Например, ассоциативные эксперименты авторов доказывают: за последние 25 лет прежде всего в сознании молодежи растет авторитет закона, но, увы, уменьшается ценность труда; иерархия этических приоритетов личности зависит от места жительства, а универсальные процессы сознания, которые руководят вербализацией объекта, приводят к различным результатам у разных людей, поскольку сами эти операции могут протекать неодинаково. В связи с этим по-разному видятся свойства предмета, он нетождественно членится на элементы и монтируется в сознании и речи, акцентируются не одни и те же отличительные признаки объекта, наконец, он проецируется на разные эталоны. Ментальные различия будут нарастать при межпоколенческой и межкультурной коммуникации. И если их не учитывать, они могут сделать любое сообщение бесполезным.

Ключевое понятие, на которое спроецированы частные аспекты исследования, реципиент-дизайн (с. 6) ${ }^{1}$, т.е. настроенность сообщения на реципиента, ментальные миры коммуникантов, а также на языко- вые, структурные и процессуальные факторы коммуникации. Последнее (скажем, коммуникативные условия, риторические средства языка), пожалуй, разработано в наибольшей степени в стилистике и риторике и знакомо читателю.

Когда авторы говорят о стилистических ресурсах при анализе языкового материала, может создаться впечатление присутствия на семинаре по практической стилистике. Но стилистической терминологией это сходство, пожалуй, и ограничивается, поскольку авторы выбирают технологический ракурс - отбирают материал не только с точки зрения иллюстративности, но и с точек зрения 1) его продуктивности, частотности, типичности; 2) создаваемых им коммуникативно-стилистических эффектов, 3) прогноза понимания сообщения; 4) обучения читателей продуктивным формам общения; 5) профилактики неэффективных, провоцирующих непонимание / недопонимание / неправильное понимание речи.

Анализу и систематизации подвергаются все основные элементы структуры коммуникативного акта (по схеме Р. Якобсона); все основные сферы общения: обиходно-бытовая, деловая, художественная, научная сфера, средства массовой информации. Внимание исследователей направлено не столько на описание структурных, процессуальных, дискурсивных особенностей функциональной области, сколько на выявление своеобразия эффективного речевого поведения в рамках определенного дискурса. Что предпочтительно в одном дискурсе - может быть запрещено в другом. Скажем, если подчиненный обращается к вышестоящему с просьбой что-то разрешить и тот говорит: Разрешаю / Не разрешаю - это прогнозируемое иерархическими отношениями, ожидаемое и потому эффективное речевое поведение. Если же пассажир в автобусе говорит другому: Разрешите выйти, 
а тот отвечает: Разрешаю! - это провоци рует агрессию (с. 26).

Помимо качеств адресата и адресанта (их компетенции, настроенности на общение, коммуникативных стратегий, культурной и психологической совместимости, скажем, обоюдного чувства юмора, коммуникативных ожиданий; свойств языкового кода и соответственно кодирования и декодирования сообщения) подробно анализируется текст как «серединная составляющая» процесса коммуникации между адресантом и адресатом.

Итенциональность, адресованность, диалогичность, эпистемическую ситуацию, среду и сферу общения авторы выделяют как определяющие в выборе вербальной формы произведения, доказывают, что смысловое развертывание, лексика и грамматика эффективного текста определяются этими качествами. Но даже идеальный текст не только допускает, но и предполагает разночтения: смысловое приращение возникает за счет фоновых знаний адресата. Текстовые смыслы адресата и адресанта могут быть идентичны только в одном случае - в общении механизмов.

Причем неоднозначность трактовки текста касается и сфер (деловой и научной), принципиально ориентированных на ее устранение. Выделяются дискурсивные и ментально-личностные условия, провоцирующие непонимание и коммуникативные сбои. Такова, например, терминологическая синонимия (ее быть не должно, но по разным объективным причинам она есть) и тезаурус ученых, которые, работая в различных научных школах, пользуются разным научным лексиконом, говоря об одном и том же.

Точно так же большое внимание исследователи уделяют условиям успешности коммуникации в СМИ, в частности, достаточно подробно разбираются стратегии и тактики, которые позволяют создать впечатление партнерства адресата и адресан - та. Последнее принципиально важно, поскольку средства массовой информации идут по пути установления партнерских, равноправных отношений с аудиторией по крайней мере, создают такую иллюзию.

Монография состоит из трех глав. В первой определяются критерии эффективности коммуникации и решаются общие вопросы влияния языкового сознания коммуникантов на успешность общения. Вторая посвящена участникам коммуникации, ее типам, адресату, адресанту и тексту. В третьей главе речь идет о коммуникативной технике эффективного общения, в частности о выборе средств в зависимости от его целей, об эффектах предпочтения активной или пассивной позиции, об имплицитных смыслах высказывания.

В центре внимания исследователей формы эффективного общения, но как фон им противопоставлено то, что создает коммуникативные риски, снижает его успешность. Причем анализируются типичные, массовые явления: например, в СМИ это грубость, агрессия, злоупотребление неосвоенными заимствованиями, лакунарность или, наоборот, излишняя детализация текста.

Анализируется большой и разнообразный языковой материал, и в этом монография продолжаеттрадицию классического филологического исследования, в основе которого - языковая практика.

В целом исследование не лишено некоторого романтизма: все наблюдения и выводы исследователей основаны на предположении, что коммуниканты всегда стремятся соблюдать принципы кооперации и вежливости. Но помимо кооперативных распространены и некооперативные стратегии. Причем, по крайней мере в СМИ, часто грубость, агрессия, эпатаж результат продуманной информационной политики, инфотейнмента.

Можно ли говорить об эффективности таких стратегий? И если да, то насколько 
их критерии совпадут с признаками кооперативного общения, в стратегической основе которого сотрудничество и вежливость?

Адресовано исследование не только ученым, но и самому широкому кругу читателей. Оно может (и должно!) быть ис- пользовано в курсах культуры речи в школах и вузах и будет интересно всем, кто хотел бы овладеть искусством общения. Любое дело начинается с коммуникации, и хотя красноречие не гарантирует его успеха, отсутствие коммуникативных навыков уничтожит на корню любое начинание.

\section{Примечания}

1 Здесь и далее книга «Эффективность коммуникации: понятие, роль адресата и адресанта, основные приемы ее достижения» цитируется с указанием страницы в круглых скобках.

\section{Библиография}

Рискогенность современной коммуникации и роль коммуникативной компетентности в ее преодолении: моногр. / под ред. О.Б. Сиротининой, М.А. Кормилицыной. Саратов: Изд-во Саратовск. ун-та, 2015.

Хорошая речь: моногр. / под ред. М.А. Кормилицыной, О.Б. Сиротининой. Саратов: Изд-во Саратовск. ун-та, 2001. 